\title{
A Study on Squatter Settlements of Kathmandu Using GIS, Aerial Photography, Remote Sensing and Household Survey
}

\author{
Kiran K.C.*, M.Sc. Dissertation Work, 2010, SchEMS, Pokhara University, Nepal \\ (Programme Officer, NTNC, Nepal, itskrn@gmail.com) and \\ Dr. Krishna Pahari**, Research Advisor, (National Advisor, UN-WFP, Nepal, krishna.pahari@wfp.org)
}

\section{Keywords}

GIS, remote sensing, GPS, aerial photography, landuse change, squatter settlement, house hold survey.

\begin{abstract}
The study was done to explore various issues facing by the squat dwellers of two densely populated squatter settlements of the Kathmandu valley (Manohara and Thapathali). A series of temporal satellite imageries along with orhtophoto were analyzed and mapped focusing the food security and their livelihood conditions, sanitary and hygienic conditions and the flood hazard assessment. The study revealed that there has been a drastic landuse change in the Manohara area as compared to the Thapathali one. The squatter settlement that currently exists is found to have been in the flood plain. The household survey has disclosed that a majority of squatters who have settled in these places belong to Janajatis and they have mainly migrated from the hilly region and the surrounding districts of the Kathmandu valley. Besides, drinking water tested from both of the areas is contaminated with high concentration of Nitrate and Coliform. Hygienic conditions are also very poor as toilets lie along the river banks resulting in the depletion of the river quality and the scenic beauty of the surrounding environment. The community-based flood hazard mapping done with the GPS survey has revealed that all the settlements from both of the areas had been inundated in the month of July in 2009. In both area, people are deprived of basis amenities and they have been neglected by the concerned government authorities. Adequate research on scientific basic is an urgent need so as to draft a clear cut specific policy that can address their issues and stop environmental deterioration, destruction of beautiful green grassland and the sanitary conditions.
\end{abstract}

\section{Introduction}

Urbanization in Nepal has not been uniform throughout the country with major urban areas concentrated within the Kathmandu Valley. Historical value of national importance sites like Basantapur Durbar square, Patan Durbar square and
Bhaktapur Durbar square listed in UNESCO world heritage sites are in pitiful state and these sites along with other things having traditional values and importance like stone spouts, natural ponds have been drying. The environmental problems have been compounded due to the uncontrolled rural-urban migration and haphazard settlements within the cities which is now threatening a good quality of life. In addition, there is already a serious shortage in availability of basic amenities like fertile agricultural land, good quality of drinking water, fresh air, etc.

Social and environmental problems associated with the growing slums and squatters in the urban areas are a significant problem of national concern in developing countries like Nepal. In 1985, it was estimated that there were only 17 squatter areas in Kathmandu, but the number has gone up to 40 now. Among the 40 settlements, majority (24) are situated along the river banks of Bagmati, Manohara, Bishnumati, Dhobikhola and Tukucha. There are a total of 12,726 people $(6,612$ males and 6,114 females) living in 2,735 households in the 40 squatter settlements of the valley (Lumanti; February 2008). Similarly, about $2.9 \%$ of the total population of Kathmandu lives in informal squatter settlements (KMC/ WB, 2001).

\section{Study area}

The Study area comprises of two largest and densely populated squatter settlement areas inside the Kathmandu Valley i.e., Bagmati River (Thapathali squatter settlement) and Manohara River (Manohara squatter settlement near Jaributi area).

\section{Methodology}

The analytical methods i.e. the remote sensing analysis was done with the analysis of series of temporal satellite imageries and orthophoto in order to compare and find out changes within the study area so as to map them accordingly. The spatial data used to depict land use change, squatter's growth were as follows: 
- Corona (1967), $1.5 \mathrm{~m}$ resolution, Panchromatic.

- Orthophoto (1999), 1:5,000 scale form Department of Survey.

- Ikonos (2001), $1 \mathrm{~m}$ resolution Pansharpend image with $1 \mathrm{~m}$ resolution Panchromatic and $4 \mathrm{~m}$ resolution Multispectral bands.

- Resourcesat (April, 2005), 5.8m resolution, Multispectral.

- Quickbird (March, 2007), Pansharpened image with $60 \mathrm{~cm}$ resolution panchromatic and $4 \mathrm{~m}$ resolution Multispectral bands.

- Quickbird (March, 2009), Pansharpened image with $60 \mathrm{~cm}$ resolution panchromatic and $4 \mathrm{~m}$ resolution Multispectral bands.

The schematic flow diagram representing the remote sensing analysis is shown in fig 1. Besides these, topographic map sheets of scale 1:25,000 from Survey Department representing the study area were used and a set of household questionnaire were used for surveying livelihood condition. Advanced tool like GPS and softwares like ERDAS Imagine 9.3, ArcGIS 9.2 were used for spatial analysis and mapping. Statistical analysis of the data from household questionnaire was done with EXCEL and SPSS. The change analysis was done in order to analyze the changes over time. Analyzing different images, growth of the settlement areas, number of household increment, land use change, river line diversion were identified and mapped. Future livelihood conditions have been predicted comparing the survey status.

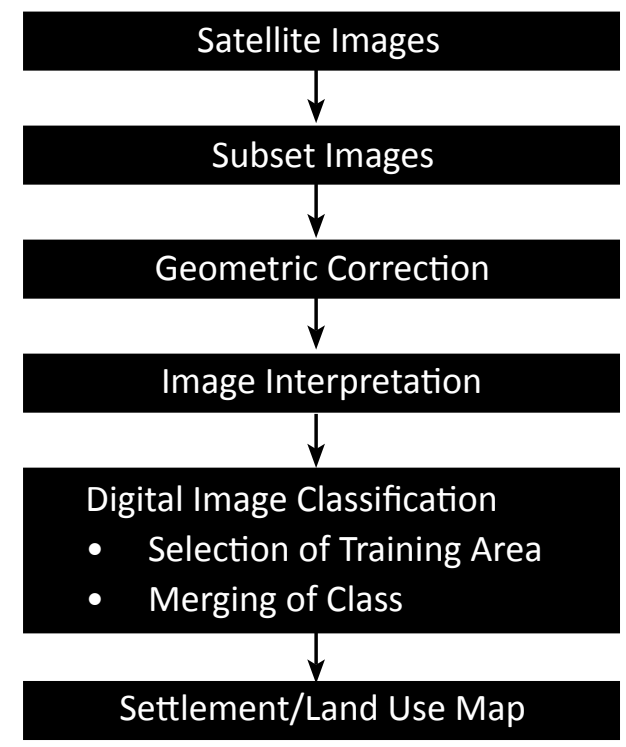

Analysis of food Security, livelihood, sanitary and hygienic condition was done with the data acquired from the household survey. Differences in status of food security, livelihood, and sanitary as well as hygienic conditions of both of the study sites were analyzed. For the Sanitary and hygienic conditions, laboratory experiment on the main source of their drinking water of the community i.e. (stone spout water) was conducted and analyzed. In the context of hygienic conditions, toilets were mapped and other details were collected through the help of checklist, discussions and observations as well. Secondary data available were also collected and analyzed for the sanitary and hygienic conditions.

Flood hazard mapping was done on the basis of community knowledge, survey and satellite images. The key informants were interviewed and discussed about the past flood events and its level of rise. In this process, survey was done with the help of GPS. The digital data were overlaid on the image and flood hazard mapping was done.

\section{Results and discussions}

\section{Squatter Settlements Growth}

Through the analysis of the imageries procured, there were no squatter settlements seen in the year 1967 and 1999 in both of the study areas. In the year 2001, a total of 11 households having an estimated population of 77 in the Manohara area and 2 households having an estimated population of 10 were seen in the Thapathali area. The number of households has increased by approximately four times, whereas it has remained constant in the Thapathali area in 2005. It has demonstrated the same trend of rise in 2009 with a total population of 5194. In contrast, the Thapathali squatter area is a recent development as the number of population that was limited to only 23 in 2007 has radically increased up to 1316 in 2009.

The settlements that grew up to 552 in the year 2007 have reached up to 742 till 2009 is seen that the settlements here in Manohara have settled for almost one decade. In maps 1 and 2, a clear picture of river line diversion is also seen from the year 1967 till 2009. It is interesting to know that the 1967 river line that had shifted away from its original course is shifting back towards the squatter settlements that are lying in the same river channel of 1967 and therefore it resembles that the settlements lying in the flood plain are prone to flood hazard causing property loss along with human injuries and deaths.

Fig1: Schematic Flow Chart of Satellite Image Study 


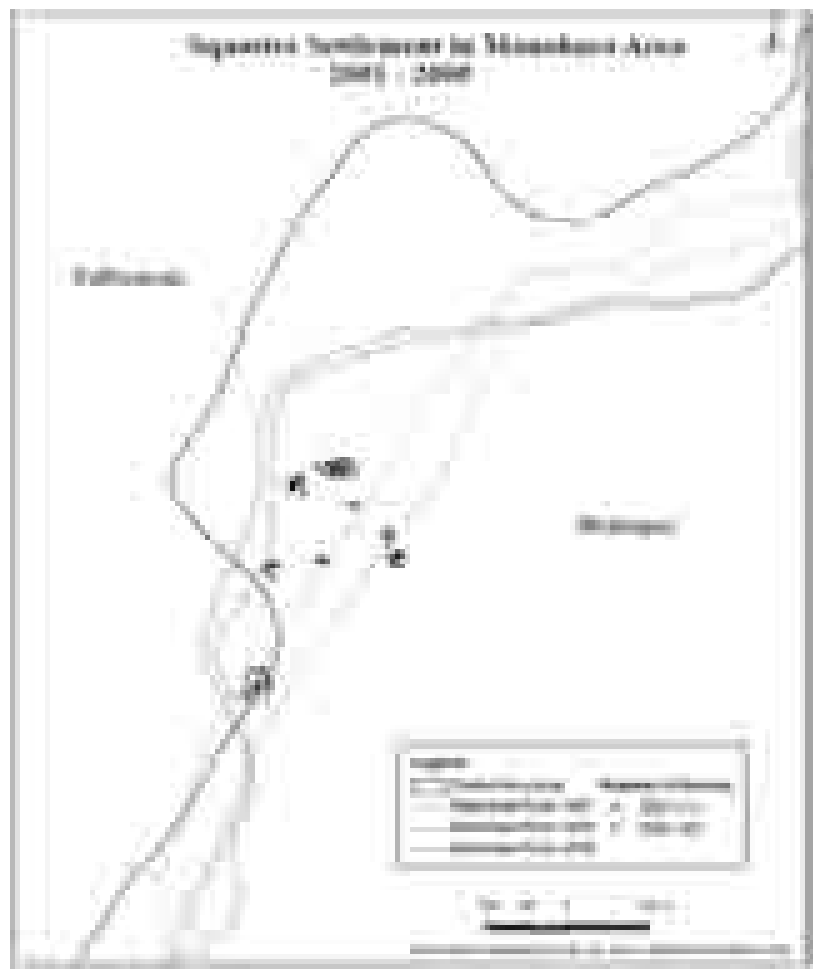

Map. 1. Squatter

Settlement in Manohara

Area (2001-2005)

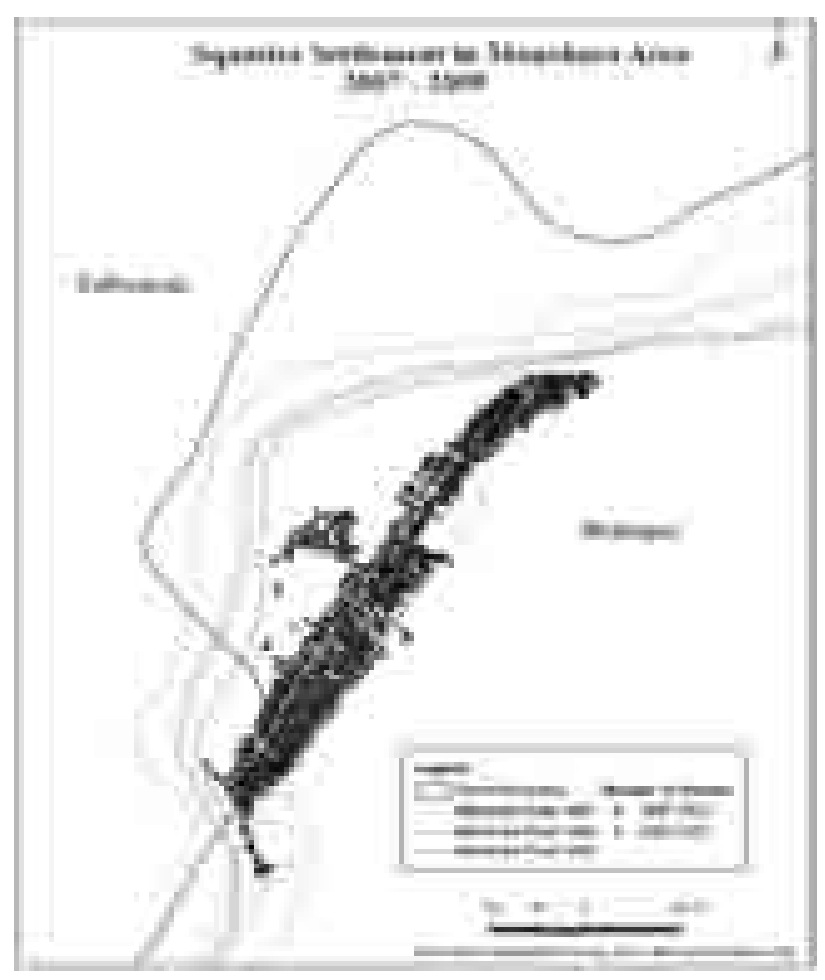

Map. 2. Squatter

Settlement in Manohara

Area (2007-2009)
Maps 3 and 4 show the growth of squatter settlements in Thapathali derived from the analysis of series of satellite images same as those used in Manohara area. Map 3 clearly reveals that the squatter settlements started from the year 2001 with only two households were as it is until 2005. These settlements which are currently adjoining to the main road are the oldest settlements lying inside the 1967 river channel. The clear picture of river line diversion from the year 1967 till 2009 is also seen in the figure. The black line resembling district boundary also changes with the change in river line as the district boundary is made in reference to river line.

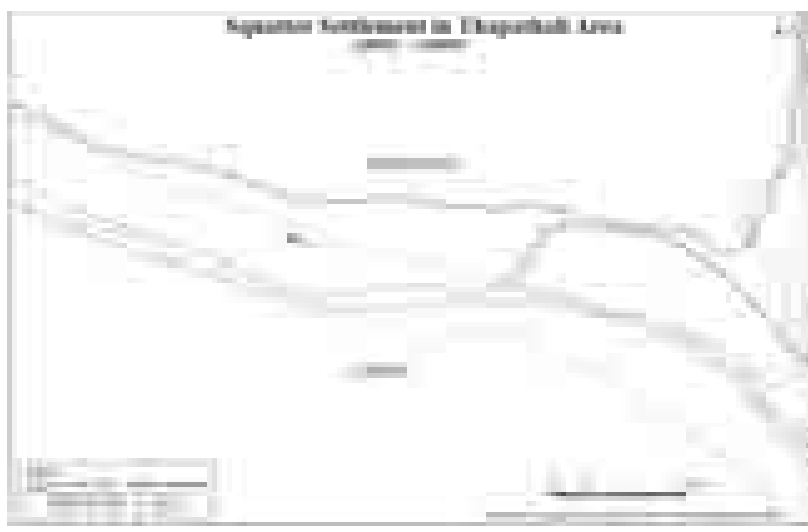

Map. 3. Squatter Settlement in Thapathali Area (2001-2005)

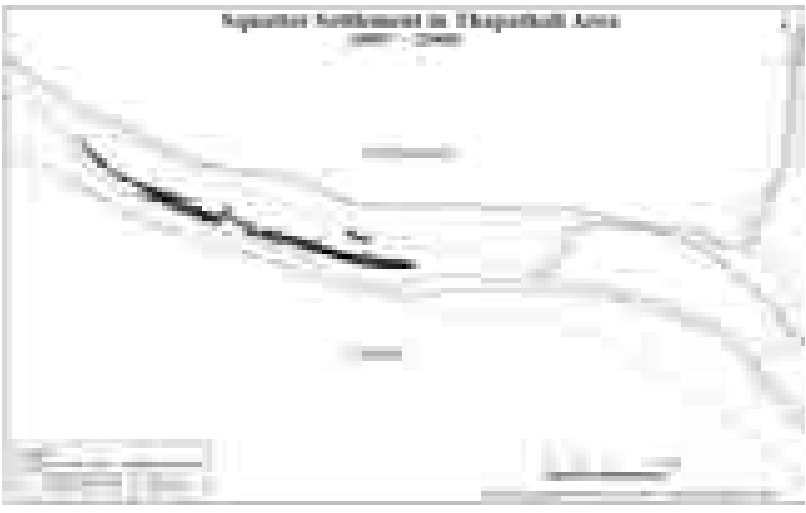

Map. 4. Squatter Settlement in Thapathali Area (2007-2009) 


\section{Land Use Change}

In the Manohara squatter settlements, mostly the agricultural land changed to the squatter settlements from the year 2005 to 2007, whereas it was mostly grassland that was used for squatter settlements from the year 2007 in Thapathali. The land use change and squatter settlements growth from the image of 1967 till 2009 of Manohara and Thapathali squatter settlements is shown from maps 5 to 10.

The map 5 has been derived from the analysis of Orthophoto of 1999 and Corona image of 1967.

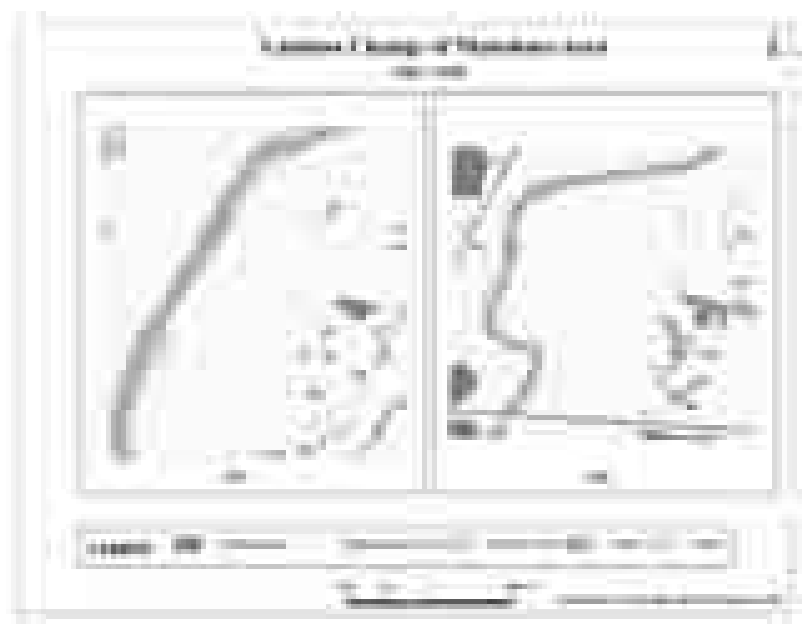

Map. 5. Landuse Change of Manohara Area

(1967-1999)

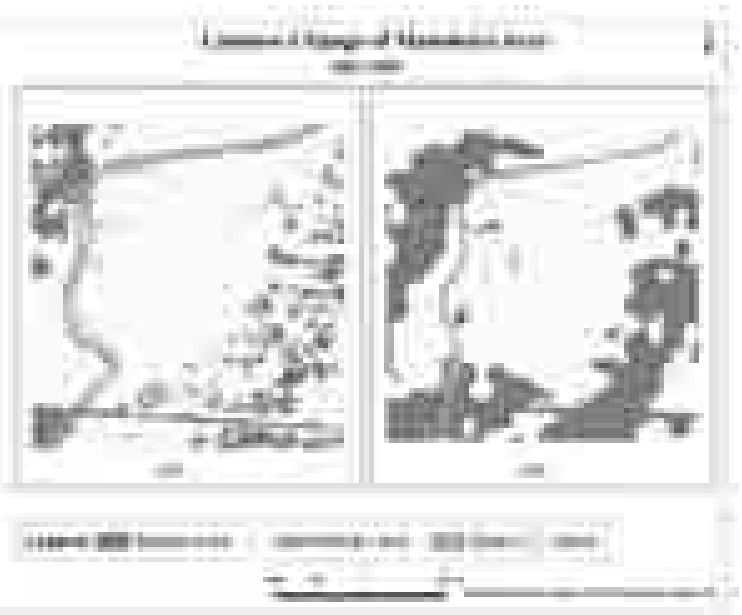

Map. 6. Landuse Change of Manohara Area

(2001-2005)

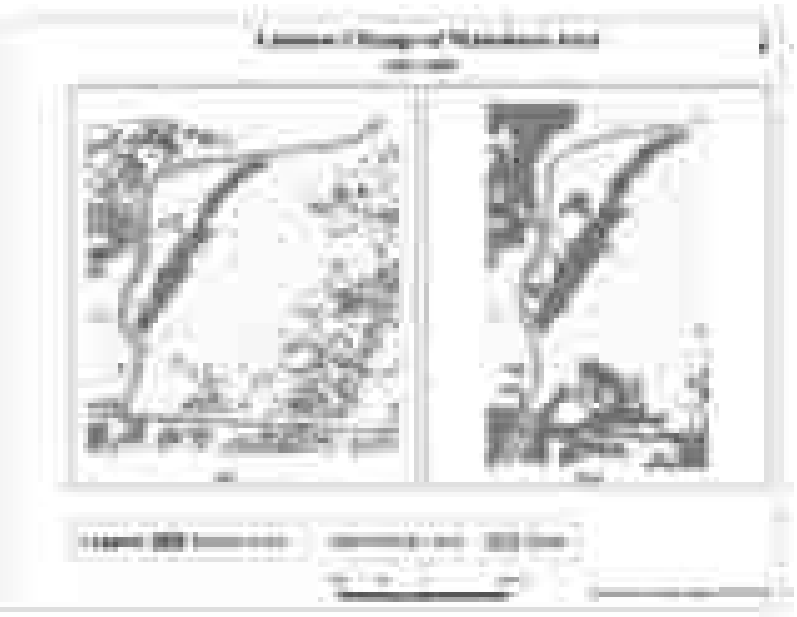

Map. 7. Landuse Change of Manohara Area (2007-2009)

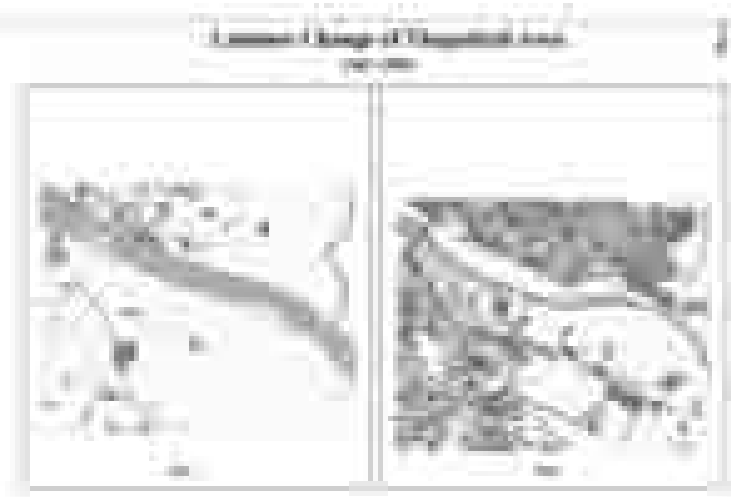

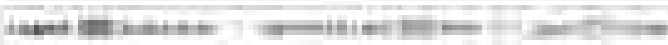

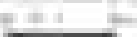

Map. 8. Landuse Change of Thapathali Area (1967-1999)

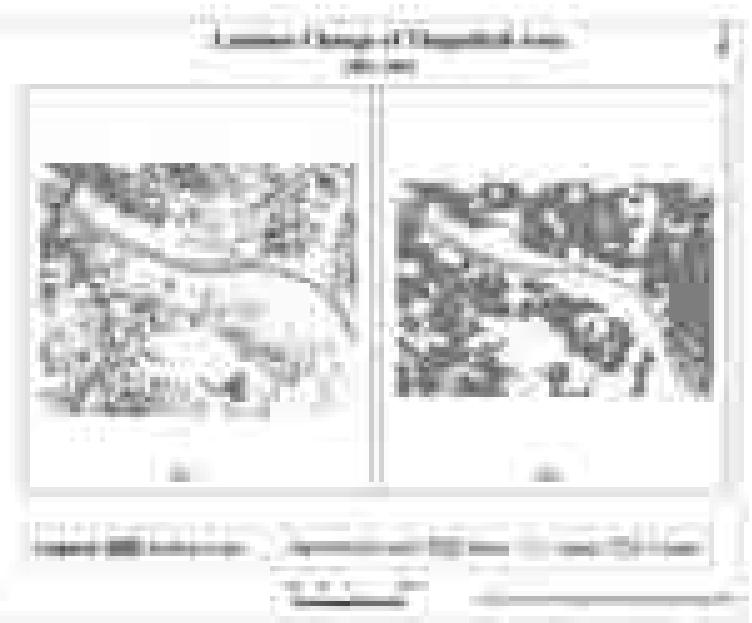

Map. 9. Landuse Change of Thapathali Area (2001-2005) 


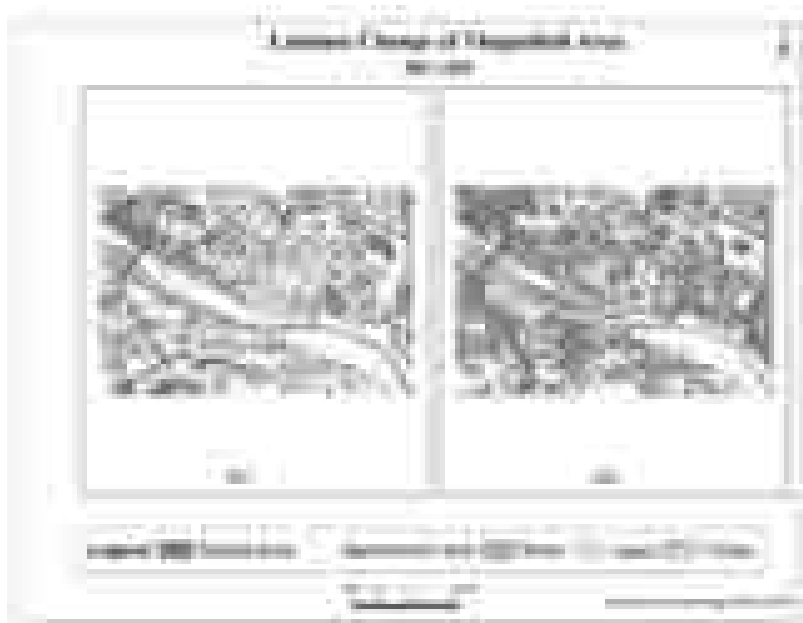

Map. 10. Landuse Change of Thapathali Area

(2007-2009)

The growth of settlements in the haphazard way clearly denotes the lack of policies, regulations and/or their enforcement. There was no significant squatter settlement in the Thapathali area until 2007, but a huge change has been seen in the Landuse of this area in last two years of time. The settlements which are lying along the bank of the Bagmati River are highly deteriorating the surrounding environment and they themselves are vulnerable to flood hazards. Maps depict that the built up areas have significantly grown with the destruction of agricultural land

\section{Food Security and Livelihood Conditions}

\section{Migration of People}

The spatial pattern of origin of squatters reveals that the highest percentages of people who have migrated to the Thapathali settlement area are from Sindhuli, Kavre and Sindhupalchowk respectively. It could be because these districts are the adjoining districts of the Kathmandu valley and it is easy for people from these places to migrate to the valley due easy accessibility.

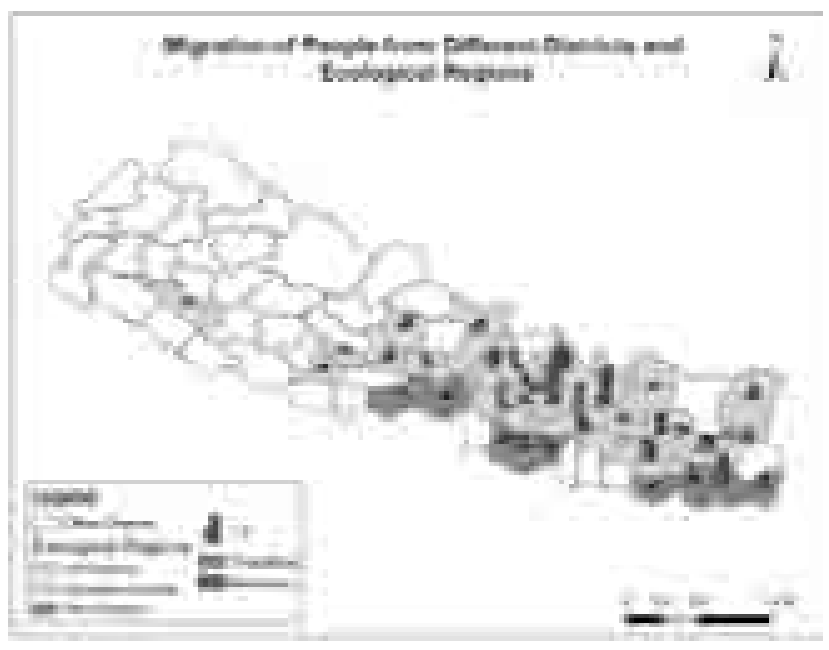

\section{Housing, Water, Fuel Access, Difficulties and Other Plans}

Nearly cent percentage people residing in these two settlements have no wish and plan to go back to their original home. The prime reason behind their unwillingness to go return home is that they are living here for free and have had better income generating opportunities in the city compared to their rural homes.

The main source of fuel for cooking, main difficulties in the past six months and expenditure are shown from figure 2 to 4 .

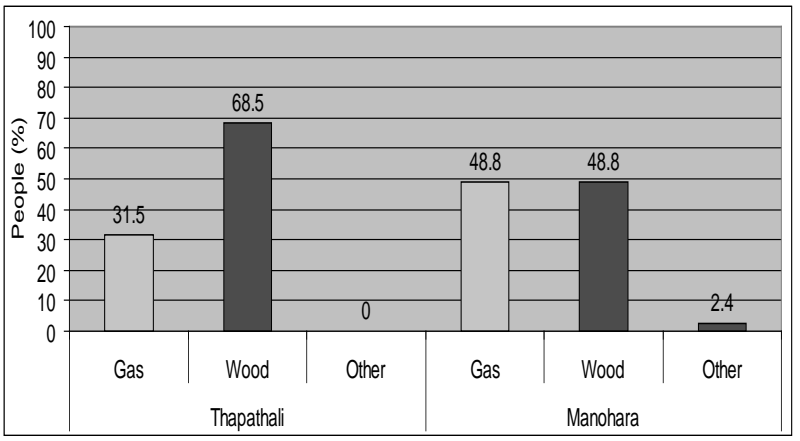

Fig. 2. Main Source of Fuel for Cooking

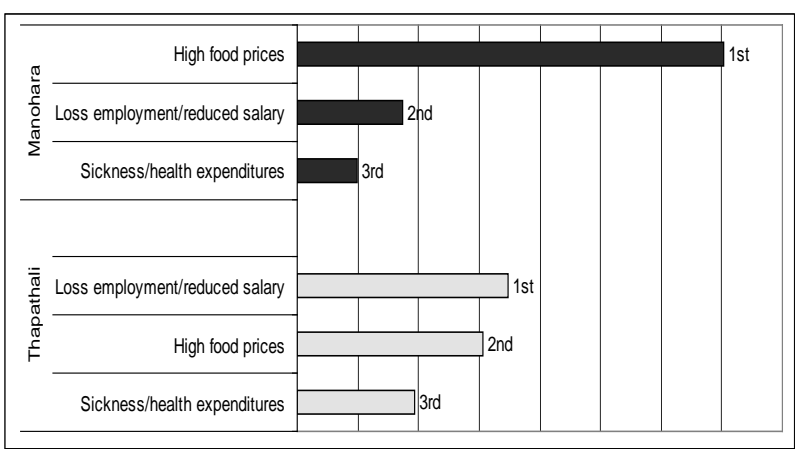

Fig. 3. First three Major Difficulties in Past Six Months

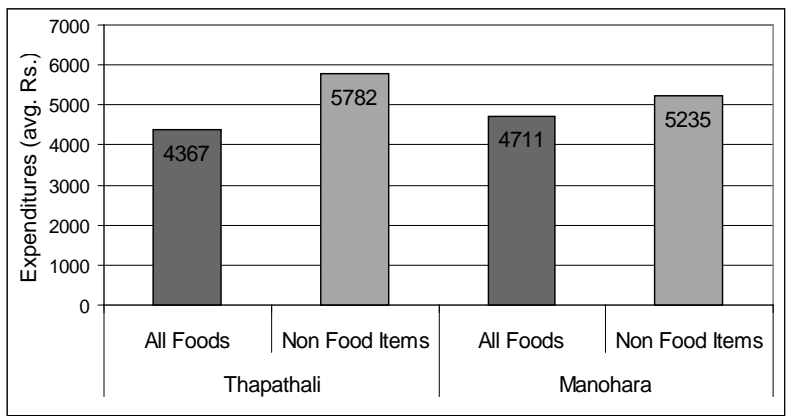

Fig. 4. Total Expenditures on Food and Non Food Items over a Month

Map. 11. Migration of People from Different Ecological Zones 


\section{Sanitary and Hygiene Conditions}

\section{Sanitary Condition}

Table 1 presents the laboratory analysis report of the drinking water and Stone Spout Water of the squatter settlements people of Thapathali and Manohara respectively.

\begin{tabular}{|c|c|c|c|c|c|}
\hline \multirow{2}{*}{ Parameters Tested } & \multirow{2}{*}{ Units } & \multirow{2}{*}{ WHO GV } & \multicolumn{2}{|c|}{ Results } & \multirow{2}{*}{ Instruments/Methods } \\
\hline & & & Thapathali & Manohara & \\
\hline \multicolumn{6}{|c|}{ PHYSICAL } \\
\hline Turbidity & NTU & 5 & $<\mathbf{1 . 0}$ & $<1.1$ & Turbidity Meter \\
\hline Conductivity & $\mu \mathrm{S} / \mathrm{cm}$ & & 894.4 & 771 & Conductivity Meter \\
\hline \multicolumn{6}{|c|}{ CHEMICAL } \\
\hline $\mathrm{pH}$ & & 6.7 & 6.7 & 6 & $\mathrm{pH}$ Meter \\
\hline Total Hardness & $\mathrm{mg} / \mathrm{l}$ as $\mathrm{CaCO}_{3}$ & 500 & 216 & 190 & EDTA Titrimetric \\
\hline Total Alkalinity & $\mathrm{mg} / \mathrm{l}$ as $\mathrm{CaCO}_{3}$ & 500 & 222 & 110 & Argenotometric Titration \\
\hline Chloride & $\mathrm{mg} / \mathrm{l}$ & 250 & 96 & 88.1 & UV-VIS Spectrophotometer \\
\hline Ammonia & $\mathrm{mg} / \mathrm{l}$ & 1.5 & 1.4 & 1.2 & Atomic Absorption spectrophotometer \\
\hline Iron & $\mathrm{mg} / \mathrm{l}$ & 0.3 & 0.11 & 0.24 & UV-VIS Spectrophotometer \\
\hline Nitrite & $\mathrm{mg} / \mathrm{l}$ as $\mathrm{NO}_{2}$ & 3 & 0.29 & 0.02 & UV-VIS Spectrophotometer \\
\hline Nitrate & $\mathrm{mg} / \mathrm{l}$ as $\mathrm{NO}_{3}$ & 50 & 62 & 93.3 & \\
\hline \multicolumn{6}{|c|}{ BIOLOGICAL } \\
\hline Coliform & $\mathrm{CFU} / 100 \mathrm{ml}$ & Nil & $>300$ & 7 & Membrane Filtration \\
\hline
\end{tabular}

Source: Laboratory Analysis Report form Water Engineering \& Training Centre (P.) Ltd.

$$
\begin{gathered}
\text { Analyzed on 16/11/2009 - 18/11/2009 } \\
\text { * - Nepal Standard (0.05 mg/l) }
\end{gathered}
$$

Nitrate $\left(\mathbf{N O}_{3}\right)$ i.e. the water-soluble molecule made up of nitrogen and oxygen is high in both of the cases. The excessive consumption of Nitrate causes 'Blue Baby Syndrome'. So, it is unfit for drinking especially for children because the high nitrate content reduce the oxygen carrying capacity of the blood. For both of the samples, bacteriological contamination is unfit for the drinking purpose. Coliform bacteria which are common in the environment are generally not harmful as such but it indicates the presence of other harmful bacteria or parasites in the drinking water.

\section{Hygienic Condition}

Map 12 presents the location of toilets in Thapathali squatter settlement area mapped by interpretation of Quick Bird image of March 2009. There were around 40 toilets in this area. Most of the toilets as seen in the maps are near the bank of the river, and they are of temporary type. The surrounding environment has been degraded and the quality of the river water has been degraded. Some of the people in this area are compelled to do open defecation as they did not participated while building any of the toilets nor do they have their personal toilets. 


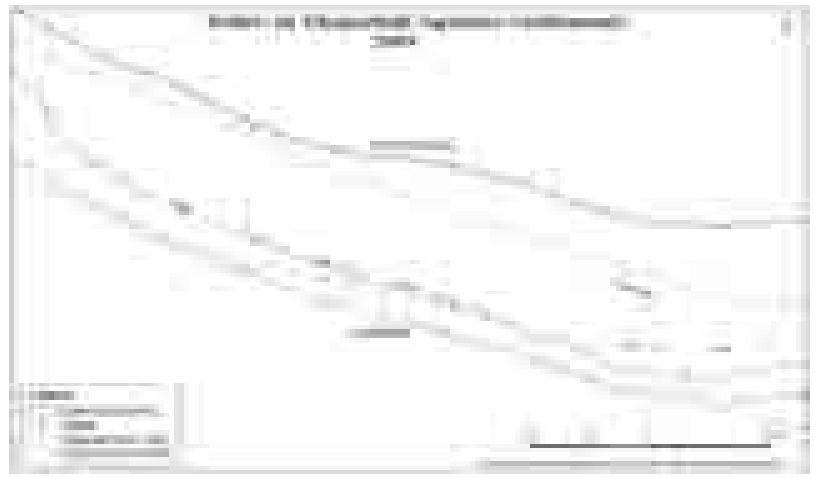

Map. 12 Toilets in Thapathali Squatter Settlement Area (2009)

\section{Community Based Flood Hazard Mapping}

The flood hazard mapping was done for the settlements area (side) on the basis of community knowledge and GPS survey was done for tracking the coordinates. With the help of checklist, the respondents were asked for the previous flood events occurred in the same area. The respondents could remember about the flood events of 2007 and 2009 as presented in the maps. The inundation maps of Manohara ara and Thapathali area are shown from map 13 to 15.
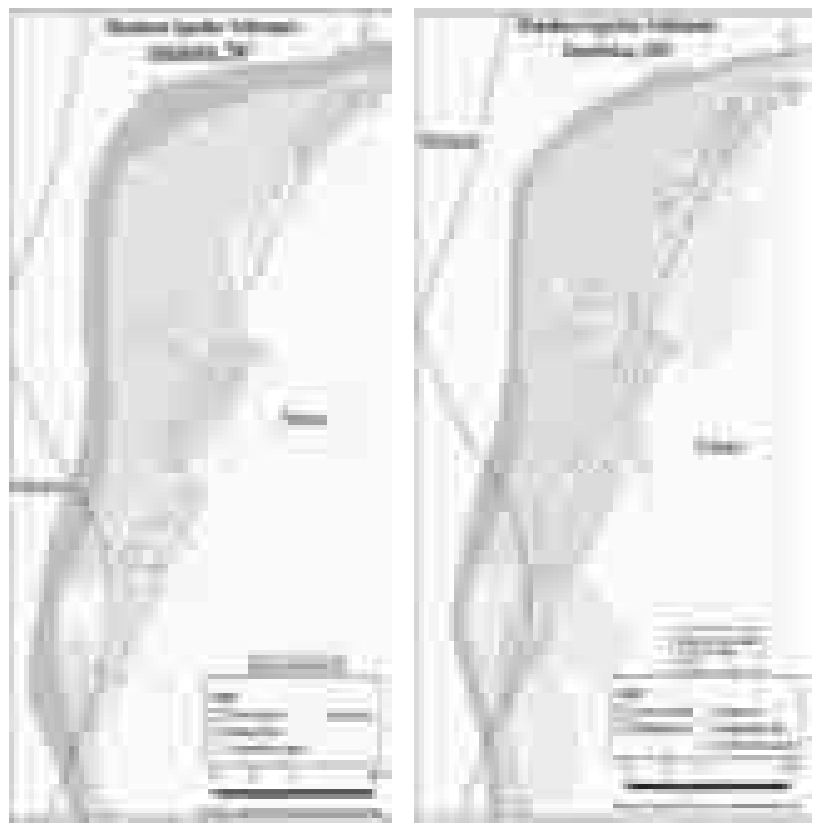

Map. 13. Manohara Squatter Settlements Inundation, 2007-2009

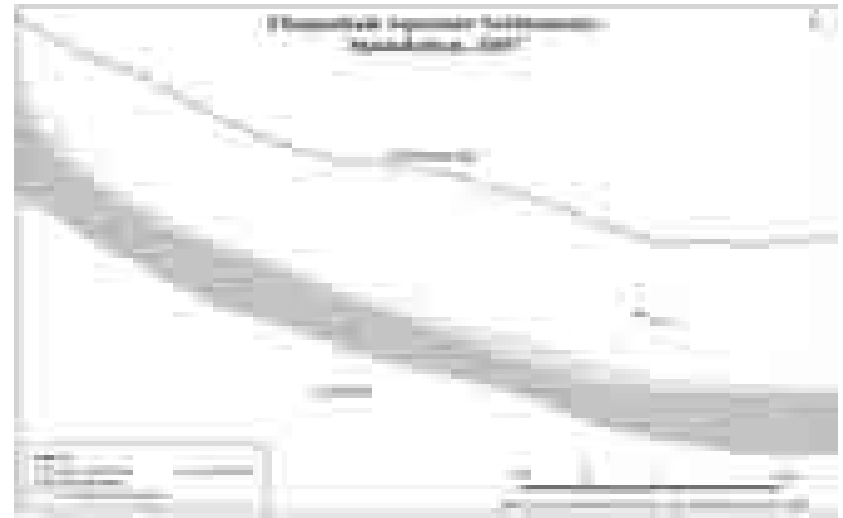

Map. 14. Thapathali Squatter Settlements Inundation, 2007

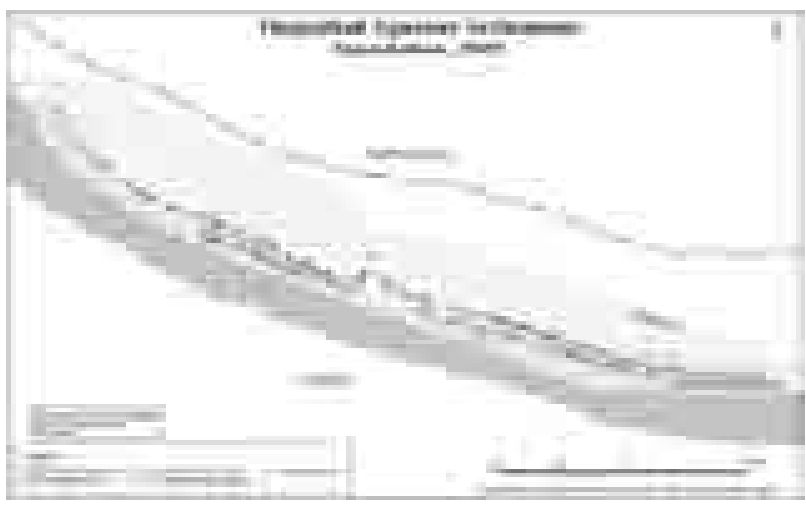

Map. 15. Thapathali Squatter Settlements Inundation, 2009

\section{Conclusion}

The present study on squatter settlements of the Thapathali and the Manohara area with the analysis of satellite images and household survey has been conducted at the right time as this study will be helpful for policy makers, planners, urban environment managers and other interested parties. The study has basically revealed the pattern of landuse changes within the study areas and the growth of squatter settlements along with the present livelihood conditions of the squatters and past flood events.

A drastic change in landuse has been seen in the Manohara area as compared to the Thapathali. The squatter settlement that currently lies is found to have been in the flood plain. A clear picture of river line diversion has been seen from the year 1967 till 2009. In the Manohara squatter settlement, mostly the agricultural land has changed to the squatter settlements from the year 2005 to 2007 during the aftermath of conflict in the country, whereas squatter settlement in Thapathali has emerged after 2007 in former grassland or bush areas. On the other hand, squatter settlements which initially started since 2001 in the Manohara area with a total of 11 households have increased to 742 by the year 
2009. Due to the lack of proper policies and regulations, people have kept migrating day by day and newer houses have been constructed and the settlement areas have expanded augmenting the deterioration of the surrounding environment.

The household survey in the study area has been compared with the image analyses which have also revealed the fact that the people in the Manohara area have settled for nearly one decade, whereas the people in the Thapathali area have come into existence during the past three years. Most of the people from Janajati communities mainly from the hilly region and the surrounding districts of the Kathmandu valley like Kavrepalanchok, Ramechhap and Sindhuli have migrated in these settlements. On the whole, nearly all the people residing in these two settlements have no wish and plan to go back to their original home. The prime reason behind their unwillingness to return home is that they have lived here for free and have had better income generating opportunities compared to their rural homes.

In both the study areas, the squatters have had only one source of drinking water i.e. stone spout. Although they opine that they do not have to boil the water as it is safe, the lab experiment has revealed that the water has contained high concentration of Nitrate and Coliform. Regarding the hygienic conditions of these areas, only around 40 toilets have been found in the Thapathali area most of which lie nearby the river banks and thus polluting the river. In case of the Manohara area, almost all households have had their own toilets and half of the toilets have been made of concrete as these settlements are a decade old. Almost everybody in these study area is discovered to have been throwing the household wastes directly into the river as the municipality never collects wastes from these squatter settlements.

The community-based flood hazard mapping done with the GPS survey has revealed that all the settlements from both of the areas had been inundated in the month of July in 2009. In both areas, the flood event had happened mainly due to the weak embankment and the sand mining activities going on rapidly along the river banks.

\section{References:}

1. Chowdhury, U.I., Problems of squatter settlements in Bangladesh: A case of Chittagong City. Dept of Sociology, Univ. of Chittagong, Bangladesh (http://dlisv03.media.osaka-cu.ac.jp/infolib/user_ contents/kiyo/DB00000200.pdf)

2. FEMA, 2003. Flood Hazard Mapping. Onlinetutorials. (http://www.fema.gov/fhm/ot_main.shtm)
Community-based flood risk assessmentusing GISfor the town of San Sebstian, Guatemala. (http://www. itc.nl/library/Papers_2005/p_jrnl/vanwesten_com. $p d f$ )

4. Goyle et. al. 2004 A profile of roadside Squatter Settlements and their families in Jaipur City. Dept of Home Science, Univ. of Rajasthan, Jaipur 302 004, Rajasthan, India. (http://www.krepublishers. com/02-Journals/JSS/JSS-09-0-000-000-2004Web/JSS-09-1-001-073-2004-Abst-PDF/JSS-09-1013-018-2004-Goyale-A/JSS-09-1-013-018-2004Goyale-A.pdf)

5. HMG (1992) The Constitution of Government of Nepal 2047 (1990). Law Books Management Board, HMG, Babarmahal.

6. HMG (1996) National Shelter Policy, 1996. Department of Housing and Urban Development, Babarmahal.

7. HMG (1997) Town Development Act, 1988. Law Books Management Board, HMG, Babarmahal.

8. HMG (2000) Local Sef-Governance Act, 2055 (1999). Law Books Management Board, HMG, Babarmahal.

9. Karki, T K (2004), An Assessment of Regional and Urban Development Policies and Programmes of Nepal. In proc. of Planning, Valuation and the Environment FIG Working Week 2004. Athens, Greece, May 22-27, 2004.

10. KMC/WB (2001) City Diagnostic Report. Kathmandu Metropolitan City and World Bank, Kathmandu, Nepal.

11. Lumanti,2008, Status of Squatter communitiesalong Bagmati River and its tributaries in Kathmandu Valley, GTZ, GoN, Lumanti, Nepal.

12. NPC (2002), The Tenth Plan (2002). HMG, National Planning Commission, Nepal

13. Paudel J.R. 2062. Study of Change in Urban Landscae. Nepalese Journal on Geoinformatics 4:39-42

14. Shakya S. 2005. An extensive study of urban poverty situation and its environmental implications in the Squatter Settlements of Kathmandu and Dharan, M.Sc. thesis, SchEMS College, PU, Shantinagar Kathmandu.

15. http//www.raosoft.com/Samplesize.html (assessed on 02 July 2009)

3. Gaurin, P., Westen van, C.J. and Montoya, L. 2004.

Nepalese Journal on Geoinformatics - 10, 2068 